\title{
両側同時性顔面神経麻㿁の 1 症例
}

\author{
横田 昌也・楠本 健夫・木下 和也・田端 敏秀
}

\section{A Case of Bilateral Simultaneous Facial Palsy}

\author{
Masaya Yokota, Takeo Kusumoto, \\ Kazuya Kinoshita and Toshihide Tabata \\ (Wakayama Medical College)
}

Bilateral facial nerve palsy is a rare disease. In the past 30 years only 11 cases of bilateral simultaneous Bell's palsy have been reported, and only three were completely simultaneous.

This is a case report of bilateral complete simultaneous Bell's palsy.

The patient was a 27-year-old man. On March 18, 1984, he noted facial nerve palsy that occurred simultaneously on both sides. He visited us with a complaint of difficulty in talking on April 24, 1984. Bell's palsy was diagnosed, because physical findings and laboratory examinations showed no evidence of systemic diseases. About 6 months after onset, his palsy had subsided almost completely bilaterally following conservative treatment.

Key words : Bell's palsy, facial palsy, bilateral facial palsy, facial diplegia

$$
\text { は じめに }
$$

両側性顔面神経麻痺は，一側性麻瘏に比較して稀な疾患であるが，なかでも，両側同時性べル麻 痺は，本邦において今だ少数の報告例しかない。

最近著者らは，非常に稀な両側完全同時性ベル麻癘の一症例を経験したので，若干の文献的考察 を加えて報告する.

症

\section{症 例 27歳, 男性}

主 訴：構音障害

家族歴：特記すべきととなし.

既往歴：特記すべきととなし.

現病歴：昭和59年 3 月 13 日，発熱，関節痛出 現し，近医内科受診，投薬を受ける．3月17日 亿両側耳痛と右眼充血出現. 3 月18日，仕事を 休んで自宅で寝ていたところ, 夕方起きた時,

\section{例}

両側の顔面運動が消失し, 顔面浮腫, 口腔粘膜 及び舌の異常に気づいた。 この時, 本人及び家 族屯顔面の左右非対称を認めていない。翌 19 日，近医内科受診し力ゼ症候群として，投薬を 受けたが効果なく， 口腔外科を紹介され，口内 炎の治療をうけた．乙の時, ヘルペスの所見は 認められなかった。しかし，顔面の運動は消失 したままで，構音障害も変化がないため，4 月 
24 日当科を受診した。

現症：顔面は軽度浮腫状で仮面様, 顔面運動 スコアは左右とも 4 点づつ（40点法にて, 安静 時非対称の項目を除く 36 点満点）であった. 雨 眼瞼は閉鎖できず，前額のしわよせ屯両側之屯 不能であり，口们にも動きはなかった（図 1 ）.

両側の耳介, 外耳道, 鼓膜に異常所見なく, その他の耳鼻咽喉科的視㟝で屯異常はなかっ た．前医で指摘されていた口内炎も消失してい た.

顔面神経以外の脳神経は異常なく, 腱反射も 正常で，病的反射も認めなかった，全身所見に 屯特に異常を認めなかった。

検查結果：一般検血異常なし．肝機能，腎機 能，電解質すべて正常範囲内であった，尿検査 正常, 血糖も正常であった. ツ反 $7 \times 6 \mathrm{~mm}$, Paul -Bunnell 反応 $($ 一), ウィルス抗体価（インフ ルエンザ $\mathrm{A} ， \mathrm{~B}$ ，アデノ，ムンプス，単純へル ペス，带状ヘルペス）上昇をみとめず。胸部X 線写真，耳X線写真，頭部 C T 異常なし．前庭 機能検査異常なし. 聴力水: 常, Tympanogram A 型.

シルマーテストでは右 $8 \mathrm{~mm}$, 左 $6 \mathrm{~mm}$, アブミ
骨筋反射は両側正常, 電気味覚㭘査は右 $20 \mathrm{~dB}$, 左 $6 \mathrm{~dB}$ であったＮ N T は両側無反応であっ た.

診断：両側完全同時性ベル麻猩

治療上経過：治療と顔面神経麻瘏の経過を図 2 亿示した。 4 月24日，初診時より，低分子デ キストラン，ヌトラーゼ，メチコバール，ビタ メジン, A T P を点滴にて投与し, また, 経口 にてビタノイリン，カルナクリン，メチコバー ル，AT P衣投与した。同時にステロイドの漸 減療法を行なった。しかし，効果がないため， 6 月 6 日入院の上， 6 月 7 日より星状神経節ブ ロックを毎日両側に施行した。また，6月20日 より低周波療法屯行なった。

発症後 4 力月経過した 7 月中頃より, 顔面運 動スコアは回復を始め, 左右多少のずれはあっ たが，9月13日現在，左 34 点，右 30 点まで回復 した.

治療後の顔貌を図 3 に示す，左に比へ，右の 口角の動きは，まだ多少回復がおくれている が, 著しい回復を示し，完全閉眼が可能となっ た.また，額のしわよせも可能である.

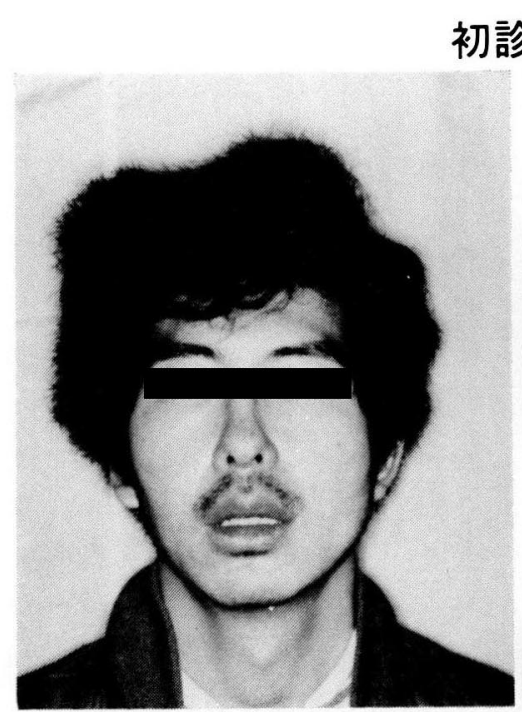

安静時

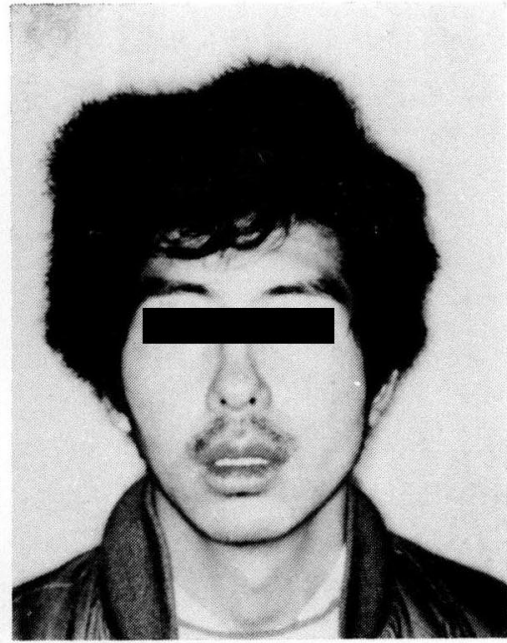

強い閉眼 イーと歯をみせる 


\begin{tabular}{|c|c|c|c|c|c|c|}
\hline 3月 & 4 & 5 & 6 & 7 & 8 & 9 \\
\hline $\begin{array}{c}{ }^{\uparrow} \\
3 / 18 \\
\text { 発症 }\end{array}$ & & & $\begin{array}{c}\uparrow \\
6 / 6 \\
\lambda / 8\end{array}$ & & & \\
\hline & & & & & & \\
\hline
\end{tabular}

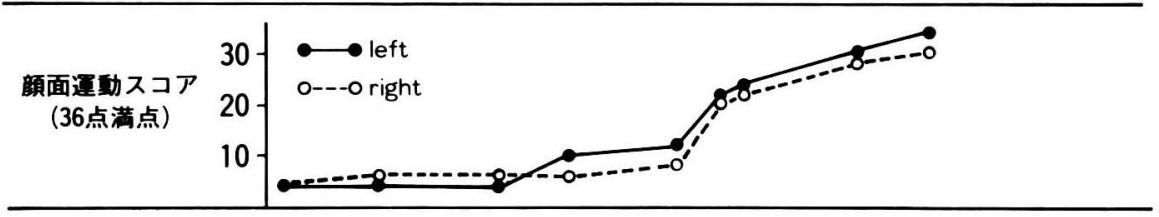

図 2 経過と治療

\section{治療後}

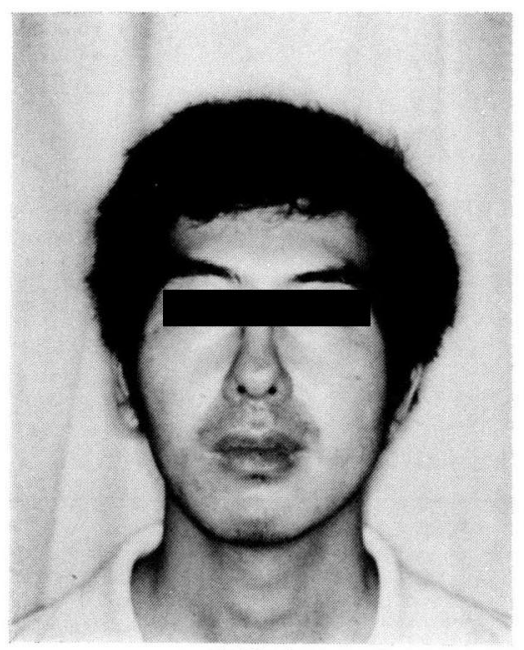

安静時

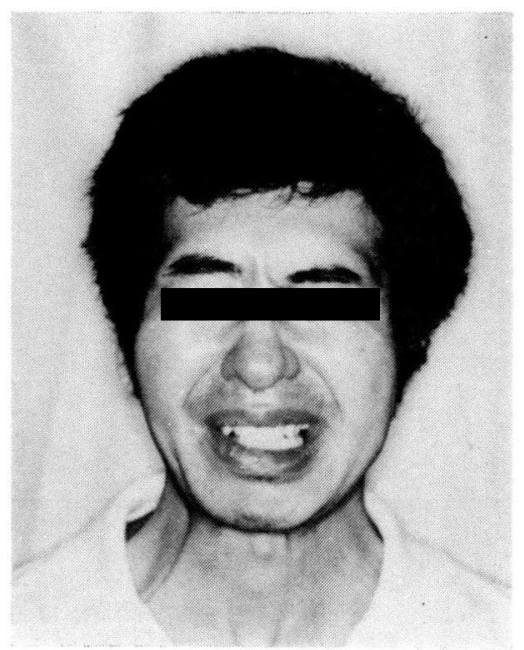

強い閉眼

イーと菓を見せる

図 3

両側性顔面神経麻瘦は全身的系統疾患汇関連 して発症することが多く ${ }^{1213)}$, 鑑別診断が重要 となるが, 著者らの症例では, 何ら系統的疶患を 認めず，ベル麻㲦と診断した。 また，本人およ び家族も顔面の麻箄に左右差を認めておらず， 両側完全同時性ベル麻瘦であると考えられる.
中村ら ${ }^{4) 51}$ は, 顔面神経麻䁬の特異例を経過 から表 1 のように分類し, 統計的に研究した. 全顔面神経麻瘏1856例中, 両側性が42例, その 内ベル麻痖が1094例で両側性ベル麻瘏が27例, 両側同時性ベル麻痺（2 週間以内）が 5 例であ ったと報告している（萇和田の報告 ${ }^{8)}$ を含む）. 
表 I 顔面神経麻瘦の経過から見た特異例の分類

\section{一側反復性}

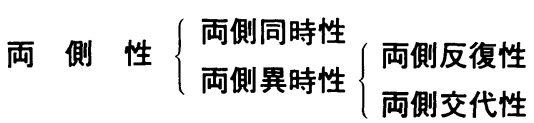

その他, 両側性ベル麻舫の頻度に関する報告は 少なく, 玉置ら ${ }^{9)}$ は, 全顔面神経麻瘏705例中, 両側性 12 例，両側ベル 4 例，小林ら ${ }^{2)}$ は， 230 例中両側性 8 例，両側ベル 1 例と報告してい る。雨側同時性ベル休盘は中村らの砢究以外に まとまった報告はなく，非常に稀なものである と考えられる.

過去30年間に，本邦において報告のあった両 側同時性ベル麻瘴の症例を表 2 に示した.

中村ら ${ }^{4) 51}$ は，両側同時性の定莪を 1 週間が 適当とした。 また，安田ら ${ }^{10)}$ は，同時性を 2 週 間以内としている。 その他, 井野ら ${ }^{13)}$ は 1 週間 とし, 玉置ら ${ }^{9)}$ は 1 か月以内としている，両側 同時性ベル麻㾝の症例について考えてみると， 表 2 に示した11例に求いて, 藤田らの症例 2 は 発症間隔の記述がなく, 玉置らの症例 4 は詳し い記述がなく，1 か月以内としか報告されてお
らないため, この 2 例を除くと， 9 例中 7 例ま でが 1 週間以内に発症している. 残りの 2 例 屯, 上出らの症例10は, 後述する両側同時性べ ル麻瘏の経過から考えて特異な症例であり，ま た，岩永らの症例 9 む, 彼ら自身が同時性, 異 時性の中間に類する同時期に発症した症例と考 えており, 著者らは, 両側同時性の定義として 1 週間が妥当ではないかと考える.

両側同時性顔面神経麻舫の経過については, 安田ら ${ }^{10)}$ や武藤 $\left.{ }^{11}\right)$ が図 $4-\mathrm{a} ， \mathrm{~b} ， \mathrm{c}$ のごとき シェーマを示している. 雨側同時性ベル麻㲦に ついて考えてみると，表 2 に示した 11 例のう ち, 両側完全同時性の 3 例を除いて, 経過の詳 しい記述のあった 6 例中 5 例（症例 $3 ， 5,6$ ， $7 ， 9 ）$ がb型を示し, 症例10の 1 例のみが $\mathrm{c}$ 型を示した.このことは, 片側性ベル麻痺の非 麻瘏側においても, 筋電図学的に異常所見が認 められること ${ }^{17) 18)}$ と関連して, 興味深いことで ある．つまり，片側性麻瘏と考えられていた中 にも, 潜在的両側性麻痖が存在していることを 示している ${ }^{13)}$ (図 4-d).

以上のととから, 左右の顔面神経の易受傷性 の違いが, 両側同時性ベル麻癘の発症間隔の違

表 2 両側同時性ベル麻瘏症例

\begin{tabular}{|c|c|c|c|c|c|c|c|c|c|c|}
\hline & 報 告 & 者 & 発症年 & 年令 & 性 & 発症 & 縓序 & 期問 & 治療 & 予 \\
\hline 1) & 楠 井 $^{6}$ & $(1958)$ & 1958 & 33 & 女 & & & 0 & 保存的療法 & 治療中だが良好 \\
\hline 2) & 藤 & $(1963)$ & 1962 & 63 & 女 & 右 & ・左 & - & 保存的療法 & 好 \\
\hline 3) & 苓和田 ${ }^{8}$ & $(1967)$ & 1966 & 31 & 男 & 左 & -右 & 6日 & 保存的療法 & $\begin{array}{l}\text { 右 } 1 \text { 力月で回復 } \\
\text { 左3力月て回復 }\end{array}$ \\
\hline 4) & 玉 置 & (1973) & - & 19 & 男 & & - & 1力月 & - & - \\
\hline 5) & 安 & ${ }^{0}(1978)$ & 1977 & 27 & 男 & 左 & -右 & 3日 & 保存的療法 & $\begin{array}{c}1 \text { 力月で完全治豦 } \\
\text { 右から回復しはじある }\end{array}$ \\
\hline 6) & 武 & $(1981)$ & 1975 & 50 & 女 & 左 & -右 & 6日 & 保存的療法 & $\begin{array}{l}\text { 右12日後治撚 } \\
\text { 左 } 6 \text { カ月後スコ }(50 / 100)\end{array}$ \\
\hline 7) & 北 & $(1982)$ & 1981 & 45 & 男 & 右 & ·左 & 4日 & 保存的療法 & $\begin{array}{l}\text { 左3n月後スコア }(40 / 40) \\
\text { 右 } 3 \text { 力月後スコア }(38 / 40)\end{array}$ \\
\hline 8) & $\begin{array}{ll}\text { 井 野' } \\
\text { 花 岡' }\end{array}$ & 4 (1983) & 1982 & 27 & 男 & 同 & 時 & 0 & 保存的療法 & 35日後，左右差なく治撚 \\
\hline 9) & 岩 & 5 (1983) & 1982 & 45 & 男 & 右 & $\rightarrow$ 左 & 25日 & $\begin{array}{l}\text { 保存的療法 } \\
\text { 右隇荷術 }\end{array}$ & 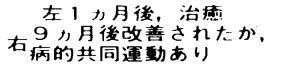 \\
\hline 10) & 上 & ${ }^{6}(1983)$ & 1982 & 34 & 女 & 右 & $\rightarrow$ 左 & 15日 & 保存的療法 & $\begin{array}{l}\text { 右順調に回復 } \\
\text { 左治桎が遷 }\end{array}$ \\
\hline 11) & 横 & (1985) & 1984 & 27 & 男 & 同 & 時 & 0 & 保存的療法 & $\begin{array}{l}\text { 左 } 5 \text { 力月後スコア }(34 / 36) \\
\text { 右 } 5 \text { 力月後スコア }(30 / 36)\end{array}$ \\
\hline
\end{tabular}


(a)

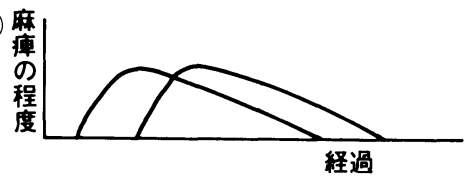

(b)

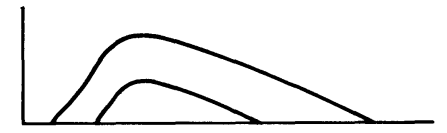

(c)

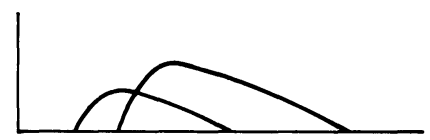

(d)

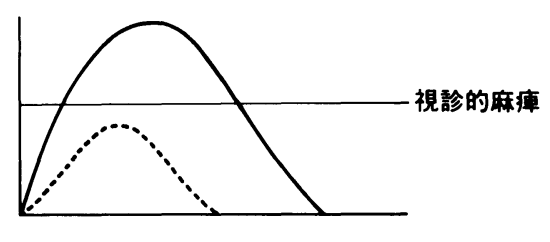

- - - - - 潜在的麻㾝

図 4 両側同時性顔面神経麻㾇の程度とその経過

いとなり，左右差が大きくなると片側性になる と考えられる. しかし，乙のことは，片側性べ ル麻㿁のすべてが両側性に障害を持っているて とを示しているのではない.

症例10は, 発症間隔が15日之長く, しかも， c 型の経過を示した特異な症例であり, 上述の 考えからしても，両側同時性ベル麻瘏とするに は異論があると思う。また, 一方, 萇和田 ${ }^{8}$ は, 発症間隔が 13 日（4 回目と 5 回目の間隔）の両 側反復性ベル麻舫を報告している. これらのこ とを考えると, この症例も, 非常に短い間隔で 発症した両側交代性ベル麻瘻と考える方が良い のではないかと思う。

両側同時性ベル麻瘏の予後は, 安田ら ${ }^{10)}$ や武 藤 ${ }^{11}$ によれば，比較的良好といわれている．表
2 に示した症例の内, 発症間隔が 1 週間以内の 7 例（症例 $1,3,5,6,7,8,11$ ) につ いてみると, 全例保存的療法を行ない, 症例 6 以外の 6 例が予後良く経過している．このこと から, 両側同時性ベル麻瘏の治療は, 先ず, 保 存的療法を施行し, 屯し, 減荷術を行なうなら ば, 先発側に施行するべきであると考える.

著者らの症例において, 閉眼時つまりベル現 象の際に, 眼球が左上方から上方へ動く現象が みられた。 これは, 初診時に閉眼不能であった ため，眼振之間違えかねないあのであった。乙 のことは, 藤田ら れている. この所見が, ベル麻盘, 特に両側同 時性ベル麻痺において，どういうことを意味す るのか, 今後の研究が必要である.

\section{ま と め}

最近経験した, 両側完全同時性ベル麻㾝の 1 症例を報告した. あわせて, 本邦における両側同時 性ベル麻瘏の報告を集計し, 若干の文献的考察を加えた。

文

1) Hora JF and Elwell RH: Facial Diplegia.

Arch Otolaryngol $83: 329 \sim 331,1966$.

2 ) 小林武夫, 新美成二, 他: 両側性顔面麻㿉につい

て. 耳喉 $46: 17 \sim 23,1974$.
献

3) Rontal E and Sigel ME: Bilateral facial paralysis. Laryngoscope $82: 607 \sim 616,1972$.

4 ) 中村光士郎, 松本 康, 他: 両側性および反復性 顔面神経麻禆の統計的観察一その 1 原因につい 
て. 耳鼻臨床 $73: 1673 \sim 1678,1980$.

5 ) 中村光士郎, 松本 康, 他 : 両側性および反復性 顔面神経麻瘏の統計的観察一その 2 ベル麻㾝に ついて. 耳鼻臨床 $74: 427 \sim 431,1981$.

6 ）楠井賢造, 玉井宏昭, 他: 末梢性両側顔面神経麻 瘦. 臨床と研究 $35: 1543 \sim 1546,1958$.

7 ) 藤田秀三, 梶原博毅：両側性顔面神経麻瘦の 1 例. 広島医学 16:564〜565, 1963.

8 ）㝨和田寛子：両側性顔面神経麻瘦の 4 例. 耳鼻臨 床 $60: 525 \sim 532,1967$.

9 ) 玉置弘光, 杉山茂夫, 他: 両側顔面神経麻㾝症 例. 日耳鼻 $76: 921 \sim 928,1973$.

10）安田宏一, 池田雄祐, 他：両側同時性ベル麻瘏の 一例. 耳鼻 $24: 370 \sim 375,1978$.

11）武藤次郎：両側同時性顔面麻瘦の 2 症例. 耳喉 $53: 93 \sim 98,1981$.

12）北佟和博, 細川 智, 他: 両側性顔面神経麻粺の 2 症例. 耳鼻臨床 $75: 1037 \sim 1045,1982$.

13）井野千代徳, 花岡真子, 他：両側完全同時性ベル
麻瘦の 1 症例. 耳喉 $55: 1023 \sim 1026,1983$.

14）花岡真子, 井野千代徳, 他：両側完全同時性ベル 麻瘏の一症例. Facial N Res Jpn $3: 45 \sim 48$, 1983.

15）岩永迪孝, 山本悦生, 他：両側性顔面神経麻盘の 一例一一側減荷術施行例. Facial N Res Jpn $3: 49 \sim 52,1983$.

16）上出一朗, 矢野原邦生, 他: 両側同時性顔面神経 麻瘦の 4 症例. 耳喉 $55: 921 \sim 928,1983$.

17) Safman BL : Bilateral pathology in Bell's palsy. Arch Otolaryngol $93: 55 \sim 57,1971$.

18）小林武夫, 黄川田徹, 他：ベル麻痺およびハント 症候群の非麻㾖側における筋電図学的異常所見. 臨床耳科 $5: 108 \sim 109,1978$.

原稿到着：昭和60年 3 月 4 日 別刷請求先: 横田 昌也 T640 和歌山市七番丁 1 和歌山県立医科大学耳鼻咽喉科学教室 